across. The very irregular grains of quartz are frequently cracked and show crush shadows. Plagioclase is not uncommon, zircon as before, and some quartz vermiculé. Possibly the rock contains cordierite.

\title{
Conclusions.
}

One characteristic feature of the rock, the irregular outline of the grains and the inclusion, or partial inclusion, of one mineral by another, may, in my opinion, be best explained as the result of movement in a somewhat viscous mass. The cracked quartzes and garnets, the lines of fracture in which are now healed, together with a confused grouping often found among the smaller particles of quartz and felspar, indicate that, at one time, the rock bas suffered from the effects of crush, from which it subsequently, more or less completely, recovered. The outlines of the quartz and felspar, which, as just remarked, may be accounted for by fluxional movement, at the same time suggest that pressure has been at work forcing them, as it were, in to the minimum space.

The presence of sillimanite and probably of cordierite, which render the alumina percentage unusually high, ${ }^{1}$ may possibly be due to an incorporation of argillaceous material, although no obvious reason exists why the magma may not have been exceptionally rich in this constituent from the beginning. However this may be, the Darjiling gneiss is certainly not a result of the metamorphosis of Gondwana beds.

Another point requiring elucidation is the presence of the hard siliceous 'eyes.' Conceivably during the movement preceding its solidification, the magma picked up small fragments of a foreign rock, which, being softened and permeated by their liquid surroundings, have resulted in the mineral assemblage seen. The graphite must have formed, if not from igneous fusion, then from a state closely approaching it. The structure as a whole is indicative of crystallization where freedom of molecular movement was restricted. ${ }^{2}$

To Canon T. G. Bonney I am indebted for many valuable suggestions which are embodied in the preceding notes.

\section{NOTICES OF MEMOIRS}

I.-Iae-Erosion in the Cuillin Hills, Skye. By Alfred HARKkR, M.A., F.G.S. Trans. Royal Soc. Edinburgh, 1901, vol. xl, pt. 2, pp. 221-252.

IHOSE who are interested in hill-climbing will know that 1 "Sligachan, in Skye, is the rock-climbing centre par excellence of the British Isles"; and as Mr. Charles Pilkington further remarks in the fascinating Badminton volume on Mountaineering, "The Alpine climber will find an additional interest in the district from

1 See Mr. J. J. H. Teall's Pres. Adadress to Geol. Assoc., Proc. Geol. Assoc., 1899, rol. xvi, pp. 72,73 .

2 See paper by Canon T. G. Bonney, Quart. Journ. Geol. Soc., 1891, vol. xlvii, p. 105. 
the remarkable indications of former glaciers; in some places it would seem as if they had disappeared but a few years previously, and occasionally, whilst climbing some smoothly rounded buttress, one almost expects to see the ice itself creeping through the next depression."

More than fifty years ago J. D. Forbes drew attention to the traces of ancient glaciers in the Cuillin Hills, but it has remained for Mr. Alfred Harker to work out and portray in masterly style the somewhat complex glacial history of this mountainous region.

The Cuillins, though formed of rocks wholly younger in age than the London Clay, are better entitled to take rank as mountains than any other elevations in Britain. The main range takes a semicircular form; it is built up of a great laccolitic mass of gabbro, and its sharp and rugged peaks rise in many places above 3,000 feet. Separated from these by Glen Sligachan is a range of 'Red Hills' formed of granite and granophyre, whose smooth and dome-like elevations, mostly under 2,500 feet, appear in marked contrast both in colour and outline with their dark and grim neighbours. Those who tread the stony track-way from the Sligachan Hotel to Loch Coruisk, may feel fatigue at the end of their journey, but they cannot fail to be fascinated with the grandeur of the Glen.

Mr. Harker points out that during the period of maximum glaciation these Skye mountains sustained a small local ice-cap, round which the great Scottish ioe-sheet flowed north-westwards and south-eastwards, traversing the peninsula of Sleat, the islands of Pabba and Raasay, and that portion of Skye which lies north of Portree. Both the Cuillins and the Red Hills afforded gatheringground for the local ice, under which they came to be wholly buried, for its thickness was probably not less than 3,000 feet. This local ice and that of the Scottish sheet were in equilibrium for a long time along their line of confluence; but the movements of the local ice are indicated by the directions of stria on rock-surfaces, and by the distribution of boulders of local and recognizable rock-types. There is a noticeable absence of foreign boulders in central Skye, except near the shore, where they occur occasionally up to as much as 75 feet above sea-level. Along this margin, however, there are. relics of the 'hundred foot' raised beach, which prove that the land stood lower by that amount at the close of the Glacial Period.

Interesting observations are made on the movement of the ice during the great glaciation, and it is pointed out that the strix necessarily give only the direction of movement of the lower layers of the ice, and this appears to be true also in great measure of the dispersal of boulders.

The natural outward flow of the ice was in general closely guided, as regards its lower layers, by the form of the ground, but as the land for many miles from the Cuillins was wholly buried in ice, the form of the ground exerted only a partial control over the direction of flow. Thus it is not improbable that the upper layers followed in places a somewhat different course from that proved with regard to the lower layers. 
The author points out that while the carving out of the main features of mountain and valley was due to aqueous erosion in pre-Glacial times, the actual details of the relief are due to the action of ice and frost during the Great Ice Age. Before glaciation the drainage system was a fully established one, and erosion was practically at a standstill, as it is under present conditions. ${ }^{1}$ Hence the effects of ice and frost action remain practically without modification by later agencies; and almost every square foot of the surface bears the stamp of glaciation. It is clear, as the author remarks, that the ice has been in close contact, throughout its whole extent, with the subjacent rocks, and has forced its way into hollows and openings, vertically and horizontally, in a fashion which argues effective plasticity in its lower layers.

He points out that it is practicable to distinguish the features due to glacial from those due to aqueous erosion. The work of the ice was something more than a mere excoriation of the surface, and in comparing the work of ice and of water he observes that " a sand-grain gripped in the sole of a glacier, or of an ice-sheet thousands of feet in thickness, must be incomparably more efficient as a graving tool than the same grain rolled along the bed of a stream." Ice-action, then, must be rapid compared with that of running water; its work is done, moreover, with little or no chemical co-operation, and instead of the relief produced by ordinary weathering agents, features are carved out of the rock-complex in a fashion wholly irrespective of lithological differences or geological structure. Lateral erosion, too, comes in unfettered by any consideration of 'base-level,' and valleys may be widened as well as deepened and their sides straightened.

Attention is drawn to the formation of cirques or corries and of small rock-basins on their floors. The erosion of these was dependent upon an adequate supply of débris or abrading material at the under surface of the ice, and as the excavation of the higher cirques proceeded the dividing ridges became intensified. On the principal ridges, which acted as ice-sheds, ice-erosion necessarily failed for want of a tool to work with.

The author observes that if we take the Cuillin district as a type, it appears that ice-erosion does not, like water-erosion, work constantly towards the establishment of an even gradient along a valley in which it operates. Erosion will be most efficient when the pressure below the ice is greatest, that is, when the thickness is greatest, and differential erosion will operate so as to exaggerate inequalities. This would be arrested when the lower layers of the ice begin to be ponded in the lee of a strong feature, and the upper layers slide over them. Thus, rock-basins in valleys are dependent not merely on glacial erosion, but on glacial erosion operating under certain local conditions and in more than one way. Detailed observations and soundings made by the author and

${ }^{1}$ See article by A. Harker on Subaërial Erosion in the Isle of Skye : Geol. MaG., 1899, p. $48 \tilde{s}$. 
Mr. T. A. Falcon on Loch Coruisk, show that it occupies an area of two rock-basins, which have been excavated by ice-action.

Evidence is brought forward to show that succeeding the great glaciation there was a minor glaciation due to the action of glaciers occupying the valleys, at a time when the obstruction caused by the Scottish ice-sheet had been removed, and when the Skye ice was free to follow a course more in accordance with local topography. The author observes that the distribution of the cirques suggests a connection with the direction of sunshine; that the asymmetric character of the ridges and valleys in the outer parts of the mountain area may be attributed to the different aspects of the slopes relatively to the sun; and that therefore this influence was exerted, not at the time of maximum glaciation, but when the ice-cap had shrunk so as to occupy the valleys alone, and during the later glaciation, which was effected by glaciers only. He has not attempted in all cases to apportion the work of erosion between the ice-cap and the glaciers. His further detailed observations on the drift deposits, on the distribution of boulders, on perched blocks, and on the formation of screes will be read with profit. They furnish evidence of his careful methods of research, and of the impartial way in which on all occasions he interprets the facts.

II.-The Granite of Tulloch Burn, Arrsimre. By Professor JaMes Gerkie, F.R.S., and JoHn S. Flute, M.A., D.Sc. ${ }^{1}$

'THE granite of Tulloch Burn, Ayrshire, is a small mass occupying I an area of three or four square miles on the headwaters of the Irvine and the Avon. Much of the outcrop is covered with drift and peat, but good exposures of the granite and the contactaltered rocks can be obtained in the Tulloch Burn, a tributary of the Irvine, and on the Avon. The prevalent type is a fleshcoloured biotite-granite, which often contains hornblende and sometimes decomposed augite. This passes at its margins into rocks of intermediate or basic composition, which include various types of diorite, hyperite, and gabbro. The evidence points to the origin of these rocks by a process of differentiation, and both in this respect and in the rock species which have been developed the resemblance to the granites of the Southern Uplands is very close. The material microscopically examined includes-Graphic Granite and Granophyric Granite (in segregation veins); Biotite Granite, Biotite Hornblende Granite, Biotite Augite Granite; Tonalite (intermediate between Hornblende Biotite Granite and Diorite); Quartz Hornblende Diorite, Quartz Augite Biotite Diorite, Quartz Hypersthene Diorite; Biotite Augite Diorite, Hornblende Diorite, Hypersthene Diorite; Hyperite and Gabbro.

This mass is intrusive into the Lower Old Red Sandstone, which at Lanfine, a little west of this, has yielded Cephalaspis Lyelli. The Old Red Sandstone is indurated and often hornfelsed to a varying distance from the margin. The new minerals developed are Augite,

1 Read before the British Association, Section C (Geology), Glasgow, Sept., 1901. 
Hornblende, Biotite, Magnetite, Tourmaline, Spinel, and possibly Sillimanite; Calcite, Chlorite, and Epidote are often present, but appear to be secondary after some of those mentioned.

Many dykes penetrate the sandstones, and most of these are undoubtedly apophyses of the Granite. They are mostly Diorite Porphyrites or Quartz Diorite Porphyrites, which may contain Biotite, Augite, Hornblende, or Hypersthene. Syenite Porphyries also occur, and occasionally small veins of more acid character, which may be considered coarse-grained Granophyres. In addition to these there are several dykes of Olivine Dolerite and Andesitic Basalt, but these are not known to be genetically connected with the Granite.

III.-Notes on the occurrence of Phosphatic Nodules and Phosphate-bearing Rock in the Upper Carboniferous Limestone (Yoredale) Series of the West Riding of Yorkshike and Westmoreland Border. By John Rhodes, of the Geological Survey. ${ }^{1}$

RY kind permission of the British Association Committee on $B$ Carboniferous Zones I am enabled to announce the discovery of phosphatic nodules and of a rock having a phosphatic matrix in the Yoredale rocks of the following localities :-

\section{Phosphatic Nodules : Far Cote Gill, East Slope of Swarth Fell, Westmoreland.}

These nodules occur along with ironstone septaria in blue shales which rest on the top siliceous beds of the Underset Limestone. The nodules are confined to the lower 5 feet of the shales, and are more numerous in the lower half than in the upper half.

In the same gill, and resting on the chert of the Little Limestone, there is a layer, 3 inches in thickness, containing phosphatic nodules embedded in a fine clayey matrix. It is sprinkled throughout with glauconite grains and angular chips of quartz, and is overlain by ironstone shales.

At the same horizon as above, but $2 \frac{1}{4}$ miles to the south-east, there occurs in a gill that runs from Lambfold Crags to Lunds Church, two miles west of north of Hawes Junction, a layer of rock three inches in thickness, with a phosphatic matrix throughout. This layer, which has a crust of brown iron-ore, is rich in glauconite and quartz grains, and also contains fragments of conodonts, etc.

Phosphatic Nodules: Goodham Gill, East Slope of Swarth Fell, 2 miles north-west of Hawes Junction, Yorkshire.

The phosphatic nodules at this locality occur throughout a limestone which varies in thickness from 3 to 6 inches. This layer is underlain and overlain by shale in more or less rotten condition. The horizon is doubtful, but it appears to be about 170 feet over the Little Limestone. From the upper surface of the top bed of the Crow Limestone, Cartmere Gill, East Baugh Fell, Grisdale,

1 Read before the British Association, Section C (Geology), Glasgow, Sept., 1901. 
$2 \frac{1}{2}$ miles west-north-west of Hawes Junction, I have obtained a solitary example of a phosphatic nodule. The phosphatic nodules and phosphatic matrix examined show sponge spicules, but these are for the most part fragmentary; some are of crypto-crystalline silica, some replaced by calcite, whilst the axial canals are often filled with the same phosphatic material as the matrix. The spicules are referred to hexactinellid and to monactinellid sponges.

I am very much indebted to Dr. G. J. Hinde for notes on the sponge remains, and also to Dr. W. Pollard for testing the phosphates.

IV.-ShorT Notroes.--In Sprawozdanie Komisyi fizyograficznej, Cracow, vol. xxxvi, pp. 11, 12, Professor J. L. M. Lomnicki describes a new species of Elater, $E$. Wisnionskii, based on a right elytra found between fossil leaves in Miocene clay near Kolomea. The elytra most nearly resembles that of Elater ferrugatus, a species now living in the same European region. It is the oldest fossil insect as yet found in Galicia, those described by A. M. Lomnicki, the Professor's father, being of Pleistocene age. The paper is written in Latin, and illustrated by three text-figures.

Bolivian Fossils and Rocks.-In Sir Martin Conway's "The Bolivian Andes" (Harper, 1901) will be found appendices by R. B. Newton on some Devonian Brachiopoda and incertæe sedis, by L. J. Spencer on Bolivian minerals, and by T. G. Bonney on rock specimens collected during the expedition. The author refrains from acknowledging his indebtedness to these writers on his titlepage, and as he does not trouble to write a preface to bis volume the papers are likely to be overlooked.

$$
\text { E } 巴 V I \Psi W S \text {. }
$$

\section{The Ghological Survey of the United Kingdom.}

THEE Summary of Progress of this institution for 1900 has just been issued, somewhat tardily if we may judge by Sir Archibald Geikie's preface, the date of which (February 28th) coincides with the termination of his long period of public service.

A considerable portion of the volume before us is taken up with a description of the structure and mineral characters of the Highland schists. Reference is made to the mapping of certain "Green beds," which in the area north of the Tay are represented by fine hornblendic schists, usually containing small garnets; and to the characters by which these altered sedimentary rocks can be distinguished from the epidiorites.

In Ireland the volcanic rocks in the Silurian series have received much attention; while in Cornwall and Devon the subdivision of the "Killas," the correlation of the Lower Devonian rocks near Looe, and the various "greenstones" have occupied those engaged in the field.

The Old Red Sandstone has been studied in various localities from Caithness to South Wales. Especially interesting are the observations on the newer granites of the Southern Highlands and 